\title{
Collaborative counselling: influence on the teaching professionals' conceptions as promoters of children's communication and language
}

\author{
Fàtima Vega ${ }^{1,3, *}$, Marta Gràcia ${ }^{1,3}$ and Carles Riba ${ }^{2,3}$ \\ ${ }^{1}$ Department of Cognition, Development and Educational Psychology, University of Barcelona, Barcelona, Spain, \\ ${ }^{2}$ Department of Social Psychology and Quantitative Psychology, University of Barcelona, Barcelona, Spain and ${ }^{3}$ CLOD \\ Group: Communication, Oral Language and Diversity, University of Barcelona, Barcelona, Spain \\ ${ }^{*}$ Corresponding author. Email: fatima.vega@ub.edu
}

(Received 20 February 2019; revised 24 September 2019; accepted 24 September 2019)

\begin{abstract}
This article presents the results of an action-research project. The project consisted of a reflection process involving a year-long collaboration between a teacher, a teaching assistant and a speech therapist in a special education school, together with two researchers acting as counsellors. The reflection process sought to promote changes in the participants' approaches to working on communication and language in the classroom. This article sets out to identify and describe the processes of change in the three teaching professionals' conceptions of communication and language teaching and learning, and about their teaching role. The collaborative counselling lasted 32 weeks and consisted of a total of nine group counselling (GC) sessions. All of the nine GC sessions were transcribed in order to analyse the changes in the teaching professionals' discourse. The ATLAS.ti 7.0 program was then used to select speech quotations and to group them into thematic clusters based on content analysis. The results indicate that the teaching professionals' conceptions subtly changed during the collaborative counselling process; specifically, their conceptions about how to develop communication and language, classroom interaction, the educator's role, organisation of context and curriculum planning.
\end{abstract}

Keywords: special education teaching professionals; group counselling; communication and language teaching and learning; conceptions and beliefs; content analysis

Determining teachers' conceptions has represented an empirical object of interest since the 1990s, although a variety of labels have been used to denote the term 'conceptions', including 'perspectives', 'beliefs', 'schemata' and 'epistemology'. Teachers use these conceptions to observe the reality of the classroom in much the same way as people use glasses to interpret that reality (Luna \& Martín, 2007); however, conceptions are also 'barriers' that inhibit the adoption of different practices (Porlán, Rivero, \& Martín del Pozo, 1997). Teachers' conceptions derive from their experience, context and personal situation through implicit learning processes (Markauskaite \& Goodyear, 2014; Urbach et al., 2015), so that teachers' actions are directly influenced by how they understand teaching-learning processes. Although they are formed as a result of past experiences, they also influence how teaching practice continues, thereby determining educators' decision-making processes (Clarà, 2014). It is therefore difficult to improve educational practices without changing the way participants conceive of the teaching-learning process (Pozo et al., 2006). 


\section{Teachers' conceptions about the communication and language development process}

Studying teaching professionals' conceptions regarding communication and language development involves discovering everything they know, assume and believe about how language development and teaching-learning processes occur. Such studies also seek to understand how teaching professionals perceive the role of their teaching in all the language development process (Cash, Cabell, Hamre, DeCoster, \& Pianta, 2015; Hamre et al., 2012; Ruppar, Gaffney, \& Dymond, 2015; Schachter, Spear, Piasta, Justice, \& Logan, 2016). Some of them have focused on how teaching professionals believe that those processes promote literacy (Cash et al., 2015; Hollenbeck, 2013; Leko, Kulkarni, Lin, \& Smith, 2014; Ruppar et al., 2015; Schachter et al., 2016) or optimise adult-child interactions (Gràcia, Galván-Bovaira, Vilaseca, Rivero, \& Sánchez-Cano, 2012; Hamre et al., 2012).

Teaching professionals pay far less attention to communication and language teaching-learning than to other areas of the school curriculum (Gutiérrez \& Rosas, 2008). This is partly because educators start from unsophisticated theories about teaching-learning processes (Coll \& Martín, 2006) that are uninformed by social interactionist theory (Bruner, 1986; Kaye, 1982) and eco-functional perspectives (Bronfenbrenner, 1987), which attach importance to the context and the adult as a promoter of communication and language development. Communication and language teaching is not systematised in the early grades at school because educators understand development and language use as an innate ability, and so they consider oral language work to be a natural process that does not require specific planning for teaching (Gràcia, Galván-Bovaira et al., 2015; Gràcia et al., 2012; Gràcia, Vega, \& Galván-Bovaira, 2015; Gutiérrez \& Rosas, 2008).

Special education professionals traditionally ascribe more importance than generalist educators to communication and language teaching processes and to their own instructional role as promoters of their pupils' development (Fennick \& Liddy, 2001). The professionals who work with pupils with special educational needs (e.g., teachers, teaching assistants, speech therapists) are generally heterogeneous, and differences in terms of the training, conceptions and communication styles are observed (Urbach et al., 2015). In general, most special education teachers and teaching assistants have not received specific training in the communication and language area in strategies to promote language development, or in the use of augmentative and alternative communication (AAC; Larraz, 2006; Vega \& Gràcia, 2016). This lack of specific training is possibly the reason school professionals encounter difficulties when it comes to understanding and using the appropriate terminology in the field of communication and language. Some educators have problems differentiating between the terms communication (exchange of information by speaking, writing, signing or any non-verbal means), language (an abstract system of symbols and meanings governed by grammar rules) and speech (the physical production of sounds to create words and sentences, to communicate verbally), and use these terms synonymously, when each has a different meaning (Kumin, 2008). A similar situation occurs with receptive language (the ability to comprehend spoken language) and expressive language (the use of words, sentences, pictograms, gestures, sign language, body language and/or writing to convey meaning and messages to others; expressive language skills include facial expressions, gestures, intentionality, phonology, vocabulary, semantics, morphology and syntax), in which educators do not know the precise differences between the two skills. Hudry and colleagues (2010) explain that educators subconsciously work on the 'receptive ability' in most classroom activities and spend little time working on the 'expressive ability', especially with students who present difficulties using speech as their main communication tool and who require the use of AAC. In contrast, speech therapists are well trained in communication and language, and their knowledge includes subjects related to articulation, phonology, voice, fluency, vocabulary, grammar, pragmatics, discourse and literacy (Ukrainetz \& Fresquez, 2003). However, all these three teaching profiles (teachers, teaching assistants and speech therapists) have received little training in social-interactionist theories of developing and teaching language (Brady \& Woolfson, 2008; Gràcia et al., 2012; Gràcia \& Segués 2009; Sandvik, van Daal \& Adèr, 2014; Weitzman, Girolametto, \& Greenberg, 2006). 


\section{Group counselling collaboration model}

In this study, we designed and implemented a collaborative counselling process focused on promoting changes in the way three teaching professionals understood their work in the area of communication and language in a special school classroom. This was inspired by previous training programs for teachers, such as the 'Learning Language and Loving It' program created by Weitzman and Greenberg (2002) and other programs adapted from it (Cabell et al., 2011; Flowers, Girolametto, Weitzman \& Greenberg, 2007; Girolametto, Weitzman, Lefebvre \& Greenberg, 2007; McDonald et al., 2015; Piasta et al., 2012; Scarinci, Rose, Pee \& Webb, 2015; Weitzman et al., 2006).

This model of professional development, sometimes referred to as the 'educational counselling model', is based on the social constructivist paradigm. The bidirectional relationships established between counsellor and counselee become drivers of change in teaching professionals' conceptions (Gràcia, Ausejo, \& Porras, 2010; Gràcia et al., 2012) through a joint construction process around a task, situation or problem in which both counsellor and counselee are engaged (Martín \& Solé, 2011). This gives rise to a relationship based on reciprocal respect, familiarity and trust that is built over time (Sakız \& Sarıçalı, 2019; Yu, 2011), and the creation of spaces and opportunities helps educators analyse their conceptions, thus enabling them to 're-describe' these based on more coherent theories (Karmiloff-Smith, 1994). These changes, however, do not occur immediately and require a process of reflection on teaching practices (Delval, 2002; Markauskaite \& Goodyear, 2014). So, as a process of educator empowerment (Bogler \& Somech, 2004; Klein, 2016), participants explore positions that help them to gradually change conceptions through a capacity for self-criticism (Keiny \& Dreyfus, 1989; Schön, 1992), enabling them to re-describe these with the help of more coherent theories.

Although previous research shows that educators transform the way they understand their role as teaching professionals when they undergo processes of reflection and contrast classroom events with the counselling processes they receive (Hamre et al., 2012; Schachter et al., 2016), much remains to be uncovered about the actual influence counselling processes have on educators' conceptual changes. For this reason, the specific aim of the study was to describe how, during the group counselling process, these teaching professionals' conceptions went through a process of change regarding: (1) their understanding of communication and language development; (2) their own role as agents in this process and the strategies they could use; (3) the use of classroom organisation to optimise children's language development; and finally, (4) the need for and use of a communication plan.

\section{Method \\ Design}

The aims of the study were addressed using a case study methodology that explores theoretical presuppositions and allows researchers to interpret, understand and explore a phenomenon in its natural context (Yin, 2006). Our study was also conceived as collaborative action-research in the sense that we combined planning, action, observation and reflection on practice in a process involving a selfreflective 'spiral' (Carr, 2007). Counsellors and teaching professionals (counselees) were actively involved throughout the counselling process, sharing ideas about how to change practice and work together to modify a situation, as well as to collect information for the study (Brantlinger, Jimenez, Klingner, Pugach, \& Richardson, 2005).

\section{Participants}

The participants in this study were one special education teacher (T), one teaching assistant (TA) and one speech therapist (ST) who all work in a state special school in Barcelona province (Spain). The $\mathrm{T}$ and TA are responsible for eight pupils in the same classroom, aged from six to nine years, who have intellectual and developmental disabilities ranging from moderate to severe. The $\mathrm{T}$ is responsible for designing the curricular activities to be carried out in the classroom, and the TA assists the T during these. The ST's profile differs from the two classroom educators insofar as he is one of the school's three speech therapists and sees each of those eight children individually, in his office, two times a week for 
Table 1. Information on the Participating Educators

\begin{tabular}{|c|c|c|c|c|c|}
\hline & Gender & Age & $\begin{array}{c}\text { Years of } \\
\text { professional } \\
\text { experience }\end{array}$ & $\begin{array}{c}\text { Years } \\
\text { working } \\
\text { in the school }\end{array}$ & Qualifications \\
\hline \multirow[t]{2}{*}{ Teacher } & \multirow[t]{2}{*}{ Woman } & \multirow[t]{2}{*}{27} & \multirow[t]{2}{*}{6} & \multirow[t]{2}{*}{6} & Teaching degree \\
\hline & & & & & $\begin{array}{l}\text { Postgraduate in autism spectrum } \\
\text { disorder }\end{array}$ \\
\hline \multirow{2}{*}{$\begin{array}{l}\text { Teaching } \\
\text { assistant }\end{array}$} & \multirow[t]{2}{*}{ Woman } & \multirow[t]{2}{*}{30} & \multirow[t]{2}{*}{8} & \multirow[t]{2}{*}{6} & Job training in social integration \\
\hline & & & & & Job training in sign language interpreting \\
\hline \multirow[t]{2}{*}{ Speech therapist } & \multirow[t]{2}{*}{ Man } & \multirow[t]{2}{*}{53} & \multirow[t]{2}{*}{29} & \multirow[t]{2}{*}{20} & Psychology degree \\
\hline & & & & & Speech therapy degree \\
\hline
\end{tabular}

30 minutes each, to help them develop their communicative skills. As Table 1 shows, all of the educators have over five years' experience in the school and are well qualified, although there are differences in age, training and professional experience. Sampling of the participants was intentional (McMillan \& Schumacher, 2014); they were selected on the basis of being accessible subjects, motivated to participate in the study and presumed to have information pertinent to the research aims.

Two researchers designed and implemented the counselling. Counsellor_1 (C1), is a predoctoral fellow at the University of Barcelona. Counsellor_2 (C2) holds a doctoral degree in psychology, is a full-time professor at the University of Barcelona, and has considerable experience developing collaborative counselling programs with families and teaching professionals.

\section{Procedure}

The design of the counselling process was based on key aspects of the social-interactionist theory about communication and language development, on the collaborative counselling model, and on previous counselling processes developed (Gràcia et al., 2012; Vega \& Gràcia, 2016; Weitzman et al., 2006; Weitzman \& Greenberg, 2002). The process lasted 32 weeks and consisted of a total of nine group counselling (GC) sessions, 90 minutes in length, attended by the three teaching professionals and $\mathrm{C} 1$ and C2, held at midday in the school library. The decision to conduct GCs was based on the fact that group dynamics can stimulate discussion, and help participants to conceptualise issues in depth and allow them to make decisions together. Through a series of open questions inviting self-reflection, the participants discussed general thematic issues present in the social-interactionist theory of communication and language development. The contents of the intervention plan are described in depth in Table 2.

At the end of each GC, the educators were asked to draw up a written summary of the topics discussed and the agreements taken. During the weeks after each GC session, T, TA and ST were encouraged to work independently on a topic before implementing it in a classroom context. Parallel to the nine GCs, the intervention plan required monthly follow-up observations to monitor the teaching professionals' progress. Each follow-up observation took place approximately two or three weeks after each GC session and was recorded on video. Throughout the counselling process, selfobservation of these video recordings was used as a technique to promote reflective processes among the three professionals, during almost every GC session (Marsh \& Mitchell, 2014).

\section{Coding and data analysis}

The data sources used in this study include audio-recordings of each GC session. Data from the followup observations will be analysed in another paper, which will study changes in the educators' practice (Vega, 2018). 
Table 2. Brief Description of the Contents Discussed in Each Group Counselling (GC) Session

\begin{tabular}{|c|c|c|c|}
\hline & $\begin{array}{l}\text { The three teaching professionals discuss some } \\
\text { topics with } \mathrm{C} 1 \text { and } \mathrm{C} 2\end{array}$ & Methodology & Agreements reached and tasks set \\
\hline \multirow[t]{5}{*}{$\begin{array}{l}\text { GC_1 } \\
\text { (week 1) }\end{array}$} & \multirow{2}{*}{$\begin{array}{l}\text { Topic 1: Conceptions about the stages of language } \\
\text { development. The socio-interactive theory of the } \\
\text { development of communication and language. } \\
\text { Receptive language vs. expressive language. Example } \\
\text { of questions: How do you think children learn to } \\
\text { speak? }\end{array}$} & \multirow[t]{5}{*}{$\begin{array}{l}\text { Debate and reflection through questions } \\
\text { proposed by } \mathrm{C} 1 \text { and } \mathrm{C} 2 \text {. }\end{array}$} & $\begin{array}{l}\text { Write a summary of the topics discussed and the } \\
\text { agreements reached in GC_1. }\end{array}$ \\
\hline & & & \multirow{4}{*}{$\begin{array}{l}\text { Meet and think about possible changes in the } \\
\text { classroom organisation and in the schedule of } \\
\text { activities that would promote students' language } \\
\text { competence. }\end{array}$} \\
\hline & $\begin{array}{l}\text { Topic 2: The importance given to the professionals' } \\
\text { role in promoting communication and language } \\
\text { development in the classroom. Mechanisms of } \\
\text { educational influence: adjusted aid, scaffolding and } \\
\text { progressive withdrawal of control and responsibility. } \\
\text { Strategies to promote the development of children's } \\
\text { language. Example of questions: What is the adult's } \\
\text { role in the process of teaching and learning spoken } \\
\text { language? }\end{array}$ & & \\
\hline & $\begin{array}{l}\text { Topic 3: How their interactive style can influence } \\
\text { children's participation, comprehension and } \\
\text { interaction. Differences between directive style } \\
\text { versus communicative style: consequences for the } \\
\text { development of children's language. Example of } \\
\text { questions: With disabled children, what does the } \\
\text { process of teaching and learning spoken language } \\
\text { involve? Do we behave with them in the same way? } \\
\text { What changes when we interact with them? }\end{array}$ & & \\
\hline & $\begin{array}{l}\text { Topic 4: Typical class structure. Diversity of } \\
\text { grouping: large groups ( } 8 \text { pupils), small groups ( } 3 \text { or } \\
4 \text { pupils) and dyadic activities. Advantages and } \\
\text { disadvantages of each type of grouping. Example of } \\
\text { questions: What class structure do you feel most } \\
\text { comfortable with? Do the pupils also feel comfortable } \\
\text { with it? }\end{array}$ & & \\
\hline
\end{tabular}

(Continued) 
Table 2. (Continued)

\begin{tabular}{|c|c|c|c|}
\hline & $\begin{array}{l}\text { The three teaching professionals discuss some } \\
\text { topics with } \mathrm{C} 1 \text { and } \mathrm{C} 2\end{array}$ & Methodology & Agreements reached and tasks set \\
\hline \multirow[t]{3}{*}{$\begin{array}{l}\text { GC_2 } \\
\text { (week 4) }\end{array}$} & \multirow{2}{*}{$\begin{array}{l}\text { Topic 1. Discuss the changes incorporated into the } \\
\text { classroom organisation and the new classroom } \\
\text { schedule they created and the pupil groupings. } \\
\text { Explain the feelings created by the new organisation } \\
\text { and explain which aspects are resolved and which } \\
\text { remain unresolved. }\end{array}$} & $\begin{array}{l}\text { Debate and reflection through questions proposed } \\
\text { by } \mathrm{C} 1 \text { and } \mathrm{C} 2 \text {. }\end{array}$ & $\begin{array}{l}\text { Write a summary of the topics discussed and the } \\
\text { agreements reached in GC_2. }\end{array}$ \\
\hline & & \multirow[t]{2}{*}{$\begin{array}{l}\text { Video-observation technique: joint observation and } \\
\text { feedback. }\end{array}$} & \multirow[t]{2}{*}{$\begin{array}{l}\text { Meet and work on prioritising three or four aims in } \\
\text { the area of communication and language for each } \\
\text { student. }\end{array}$} \\
\hline & $\begin{array}{l}\text { Topic 2: Analyse the interaction between } \\
\text { professionals and children in small-group activities } \\
\text { (participation, directiveness, responsiveness, } \\
\text { expressive language, receptive language, etc.). }\end{array}$ & & \\
\hline \multirow[t]{3}{*}{$\begin{array}{l}\text { GC_3 } \\
\text { (week 8) }\end{array}$} & $\begin{array}{l}\text { Topic 1: How they feel about implementing small } \\
\text { groups in the classroom. }\end{array}$ & \multirow[t]{3}{*}{$\begin{array}{l}\text { Debate and reflection through questions proposed } \\
\text { by } \mathrm{C} 1 \text { and } \mathrm{C} 2 \text {. }\end{array}$} & $\begin{array}{l}\text { Write a summary of the topics discussed and the } \\
\text { agreements reached in } \mathrm{GC} 3 \text {. }\end{array}$ \\
\hline & $\begin{array}{l}\text { Topic 2: Importance of planning activities that use } \\
\text { the students' interests as a starting point and the } \\
\text { importance of following the children's lead, even if } \\
\text { this involves abandoning or changing the activity } \\
\text { halfway through. Examples of questions: Do you } \\
\text { think it is very important for the children to have the } \\
\text { opportunity to use their interests as a starting point? } \\
\text { What provisions have you made to give pupils the } \\
\text { freedom to change from one working group to } \\
\text { another? Do you feel comfortable with these } \\
\text { provisions? }\end{array}$ & & \multirow[t]{2}{*}{$\begin{array}{l}\text { Two agreements were reached: (1) work on the } \\
\text { prioritised aims for each student in the classroom. } \\
\text { Example of aims: Respond to closed questions with } \\
\text { YES/NO, in a coherent manner; Request continuity in } \\
\text { the execution of activities of your liking; Keep the } \\
\text { topic of conversation for longer. (2) the same aim is } \\
\text { systematically worked on throughout the day, } \\
\text { through repetitive activities and in different } \\
\text { contexts. }\end{array}$} \\
\hline & $\begin{array}{l}\text { Topic 3: Which communication and language aims } \\
\text { should be prioritised for each pupil? We reinforce } \\
\text { the efforts they have made to define the aims more } \\
\text { clearly for each pupil and we discuss which } \\
\text { activities and methodology have been planned to } \\
\text { achieve the prioritised aims. Example of questions: } \\
\text { Do you think it is important to know each student's } \\
\text { vocabulary and to tailor the strategies to each pupil? }\end{array}$ & & \\
\hline
\end{tabular}




\begin{tabular}{|c|c|c|c|}
\hline & $\begin{array}{l}\text { The three teaching professionals discuss some } \\
\text { topics with } \mathrm{C} 1 \text { and } \mathrm{C} 2\end{array}$ & Methodology & Agreements reached and tasks set \\
\hline \multirow[t]{2}{*}{$\begin{array}{l}\text { GC_4 } \\
\text { (week 12) }\end{array}$} & \multirow{2}{*}{$\begin{array}{l}\text { Topic 1: Reflect upon all the changes they have } \\
\text { been making in the classroom during the last five } \\
\text { months of the intervention. The aspects discussed } \\
\text { are: seating arrangements and other aspects of } \\
\text { classroom furniture, pupil groupings, pupil } \\
\text { participation, educators' use of conversation } \\
\text { moderation and communication rules to regulate } \\
\text { the pupils. }\end{array}$} & \multirow[t]{2}{*}{$\begin{array}{l}\text { Video-observation technique: joint observation and } \\
\text { feedback. }\end{array}$} & $\begin{array}{l}\text { Write a summary of the topics discussed and the } \\
\text { agreements reached in GC_4. }\end{array}$ \\
\hline & & & $\begin{array}{l}\text { On this occasion, they are not given any work } \\
\text { assignments to develop in self-work sessions. }\end{array}$ \\
\hline \multirow[t]{2}{*}{$\begin{array}{l}\text { GC_5 } \\
\text { (week 15) }\end{array}$} & \multirow{2}{*}{$\begin{array}{l}\text { Topic 1: Observe themselves interacting with the } \\
\text { pupils and reflect together on: (1) classroom } \\
\text { organisation; (2) student groupings, (3) the degree of } \\
\text { student participation; (4) participation management } \\
\text { by teachers; and (5) strategies to promote children's } \\
\text { leadership. }\end{array}$} & \multirow[t]{2}{*}{$\begin{array}{l}\text { Video-observation technique: joint observation and } \\
\text { feedback. }\end{array}$} & $\begin{array}{l}\text { Write a summary of the topics discussed and the } \\
\text { agreements reached in GC_5. }\end{array}$ \\
\hline & & & $\begin{array}{l}\text { Meet and draft a document in which they reflect on } \\
\text { the communicative functions they usually work on } \\
\text { with their pupils and the functions pupils use in the } \\
\text { classroom most frequently. }\end{array}$ \\
\hline \multirow[t]{2}{*}{$\begin{array}{l}\text { GC_6 } \\
\text { (week 19) }\end{array}$} & $\begin{array}{l}\text { Topic 1: Discuss the document created by the } \\
\text { educators that describes the communicative } \\
\text { functions that they and their students use most } \\
\text { frequently in the classroom. }\end{array}$ & $\begin{array}{l}\text { Debate and reflection through questions proposed } \\
\text { by } \mathrm{C} 1 \text { and } \mathrm{C} 2 \text {. }\end{array}$ & $\begin{array}{l}\text { Write a summary of the topics discussed and the } \\
\text { agreements reached in GC_6. }\end{array}$ \\
\hline & $\begin{array}{l}\text { Topic 2: Observe themselves interacting with } \\
\text { students and reflect together on: (1) the } \\
\text { communicative functions that students use. Example } \\
\text { of questions: What communication functions do the } \\
\text { students use in the video? How have you helped the } \\
\text { student to use it? (2) strategies to encourage the } \\
\text { development of children's communication functions. } \\
\text { Example of questions: What strategies do you use to } \\
\text { promote the use of certain communication functions } \\
\text { during the scenes? }\end{array}$ & $\begin{array}{l}\text { Meet and draft a document in which they explain } \\
\text { the strategies they use most in the classroom, } \\
\text { aimed at promoting pupils' participation and } \\
\text { managing turn-taking. }\end{array}$ & $\begin{array}{l}\text { Video-observation technique: joint observation and } \\
\text { feedback. }\end{array}$ \\
\hline
\end{tabular}

(Continued) 
Table 2. (Continued)

\begin{tabular}{|c|c|c|c|}
\hline & $\begin{array}{l}\text { The three teaching professionals discuss some } \\
\text { topics with } \mathrm{C} 1 \text { and } \mathrm{C} 2\end{array}$ & Methodology & Agreements reached and tasks set \\
\hline \multirow[t]{2}{*}{$\begin{array}{l}\mathrm{GC} \text {-7 } \\
\text { (week 23) }\end{array}$} & \multirow[b]{2}{*}{$\begin{array}{l}\text { Topic 1: Observe themselves interacting with the } \\
\text { pupils and reflect together on: (1) the importance of } \\
\text { their role as promoters of pupil communication. } \\
\text { Example of questions: Do you follow the children's } \\
\text { lead? Do you give the children enough time to } \\
\text { intervene? (2) their use of child-oriented strategies } \\
\text { aimed at promoting the participation of the child. } \\
\text { Example of questions: Which child-oriented strategies } \\
\text { did you use in the video? Which interaction-promoting } \\
\text { strategies did you use? Why do you believe that such } \\
\text { strategies can promote pupils' language-skill } \\
\text { development? Are the sentences you use very long? } \\
\text { Do you think you could use sentences with fewer } \\
\text { words? Would this favour children's language } \\
\text { comprehension? }\end{array}$} & \multirow[t]{2}{*}{$\begin{array}{l}\text { Video-observation technique: joint observation and } \\
\text { feedback. }\end{array}$} & $\begin{array}{l}\text { Write a summary of the topics discussed and the } \\
\text { agreements reached in GC_ } 7 \text {. }\end{array}$ \\
\hline & & & $\begin{array}{l}\text { Two agreements were reached: (1) implement } \\
\text { strategies that are considered more appropriate for } \\
\text { promoting students' language development (e.g., } \\
\text { expansions, labelling, imitation, open questions, } \\
\text { chains) in the classroom, in a more conscious and } \\
\text { systematic way; (2) reduce the use of less optimal } \\
\text { strategies (e.g., corrections, instructions,). }\end{array}$ \\
\hline \multirow[t]{3}{*}{$\begin{array}{l}\text { GC_8 } \\
\text { (week 27) }\end{array}$} & \multirow{3}{*}{$\begin{array}{l}\text { Topic 1: Observe themselves interacting with the } \\
\text { pupils and reflect together on language-modelling } \\
\text { strategies the teachers use to promote children's } \\
\text { language development. Example of questions: Did } \\
\text { you expand on the children's expressions? Which } \\
\text { words did you use to achieve this? Did you over- } \\
\text { interpret or ask for explanations of children's } \\
\text { vocalisations, words or non-intelligible gestures? } \\
\text { Which clarifications did you use? Did you use the } \\
\text { waiting strategy correctly in order to promote and } \\
\text { encourage pupil participation? Did you repeat exactly } \\
\text { what the pupil said immediately before? What } \\
\text { consequences would the use of simple phrases by the } \\
\text { teacher have for the children's expressive language? } \\
\text { Will we offer more adjusted models that are more } \\
\text { susceptible to being imitated? }\end{array}$} & \multirow[t]{3}{*}{$\begin{array}{l}\text { Video-observation technique: joint observation and } \\
\text { feedback. }\end{array}$} & $\begin{array}{l}\text { Write a summary of the topics discussed and the } \\
\text { agreements reached in GC_ } 8 \text {. }\end{array}$ \\
\hline & & & Same agreements reached in $C_{-} \_7$. \\
\hline & & & $\begin{array}{l}\text { They are given an ad hoc questionnaire, to be } \\
\text { completed individually, in which the educators' } \\
\text { degree of satisfaction and agreement with the } \\
\text { intervention carried out is recorded. This will be } \\
\text { discussed at the last group-counselling meeting. }\end{array}$ \\
\hline $\begin{array}{l}\text { GC_9 } \\
\text { (week 32) }\end{array}$ & $\begin{array}{l}\text { Final meeting. Educators and counsellors share and } \\
\text { assess the results of the satisfaction grade obtained } \\
\text { during the overall process. Each teaching } \\
\text { professional has completed a satisfaction } \\
\text { questionnaire containing } 78 \text { items on a } 10 \text {-point } \\
\text { scale, with values ranging from } 0=\text { strongly disagree } \\
\text { to } 10=\text { strongly agree. }\end{array}$ & $\begin{array}{l}\text { The instrument is read collaboratively; the three } \\
\text { teaching professionals present their individual } \\
\text { scores for each of the } 78 \text { items, explaining why } \\
\text { they have selected that score. }\end{array}$ & \\
\hline
\end{tabular}


C1 transcribed all the GCs' content, and an inductive coding process was carried out (Krippendorff, 2012), developing a multiple-level coding, moving from data to labels, codes and categories. The ATLAS-ti 7.0 (Muhr, 2013) was used to manage the datasets. Each transcript was coded by C1 and reviewed by $\mathrm{C} 2$, with disagreements resolved through consensus. Resolution involved modifying a code definition, deleting or adding a code, or changing the segment code assignment. Consistent with qualitative methodology (Bogdan \& Biklen, 1998), these discussions were ongoing and flexible in order to facilitate agreement on criteria and avoid theoretical discrepancies.

\section{Results}

Our findings derive from the codes and categories created through content analysis and comprise the quotations obtained during the analysis of the quotations made by T, TA and ST. This section highlights the process of change in each participant's quotations from GC_1 to GC_9 regarding their conceptions about: (1) communication and language development; (2) the educator's role; (3) communication style and interaction management; (4) communication work: group size and classroom organisation; (5) strategies to promote children's language development; and (6) curriculum and educational goals.

\section{Teacher $(T)$ quotations evolution during group counselling}

\section{Communication and language development}

At the beginning of the process and to answer the question 'How do children learn to use language?', $T$ cited 'use' and 'model' as explanatory factors in children's language development, both located in conceptions closer to social-interactionist theories. However, in GC_1, her quotations show that she did not conceive of her assistance as a factor in promoting children's language development at all. Rather, on occasions she considered her support 'as a crutch that might make the pupils more adult-dependent' (T_004). After GC_1, she offered no further quotations about how her assistance might hinder pupils' development, and she increasingly attributed the causes of development and improvement in children's linguistic competence to the 'language used by pupils' ( $T_{-} 138$ ) and to 'the model offered by the educator' ( $\left.T \_137\right)$. Paradoxically, at the beginning, she also referred to 'certain maturational aspects' that she believed determined the development of children's communicative competence (T_001), and in GC_6 she considered that one child's low level of social interaction could be explained as a 'personality trait' (T_051). After the GC_6 there are no more quotations where she considers the innate or maturational aspects as decisive.

\section{The teacher's role}

There are certain aspects that remain unchanged regarding T's conceptions about her role in promoting the development of children's communication. For example, quotations taken from GC_1 to GC_9 indicate that she saw calmness, communicative interest and ability to encourage pupils as important aspects of a good educator's role in the promotion of communication development. However, she was highly critical about her training in communication and language development issues. In GC_1, GC_3 and GC_5 she admitted, 'I had not received adequate training on the subject of children's language development and on managing children's interactions' (T_010; T_053; T_091). In contrast, there were no quotations about lack of knowledge in the last GC, because she considered that her role had 'gradually become more homogeneous with the roles of the TA and the ST', because they had 'received training to teach communication and it is not an exclusive domain of the ST' (T_143).

Another important moment is the shift in T's conceptions about her responsibility to reflect upon professional practice. In GC_1 she explained the way she worked in the classroom in terms of nonconscious imitation of previous models (peers, experience as a university student or a primary school pupil); but, during the collaborative process, her quotations began to refer to the importance of 
reflecting on her own teaching practice (T_144). In GC_9, she viewed such reflection as necessary to improve her performance, although she admitted this was a difficult step to take. She also expressed happiness about having made her own decisions to improve her teaching (T_144).

\section{Communication style and interaction management}

In GC_2, T conceived her communication style as 'too instructional' and considered it different from the style she uses with typically developing pupils (T_014). However, she does also justify the use of a more instructional style, arguing that 'when pupils do not have innate communicative interest it is necessary to interact with them through questions to generate communicative desire' (T_035). In GC_8, she said, 'I feel more comfortable and could work in a more natural way with pupils who spoke more and I am conscious of using a more directive style with those children who spoke less' (T_145), although she admitted in GC_9 that 'to promote children's language development, our conversational style should be more conversational' (T_146).

On the subject of managing classroom interaction, from GC_1 to GC_6 she believed she was the responsible for managing the conversation, so that each child could have communicative time, and she believed an important curricular aim was to teach pupils to listen to others. She conceived of it as her responsibility 'to stop the most communicative children from talking in order to give time to the quieter pupils' (T_109); however, starting in GC_4, she gradually became more aware that 'some of the most talkative children tried to initiate more turns by themselves and could regulate the conversations in network and become models for other children as well' (T_110).

\section{Communication work: group size and classroom organisation}

Concerning the way $\mathrm{T}$ conceived of the communication work, from GC_1 to GC_5, she considered that 'the work on communication and language was essentially better if it was planned and programmed' (T_015). In contrast, in GC_8 and GC_9, T gradually gained in the conviction that it is a useful strategy to let the children do what they want to do, based on their own interests, and that this could transform the activity in such a way that the conversation becomes more natural' (T_129, T_130).

$\mathrm{T}$ was also invited to think about the value she attached to group size, context, and organisation to promote communication development in the classroom. In GC_1, she stated that 'the number of pupils in the classroom does not affect the development of the activity or the children's involvement' (T_023). During the intervention process, she was progressively aware of the importance of group size, and, in GC_9, she admitted that 'small-group activities promote pupil participation' (T_155). At the beginning, $T$ felt 'large-group activities are comfortable and useful' (T_024); on the other hand, from GC_2 onwards, once the educators had begun to organise small-group activities, large-group activities were gradually considered less useful. Thus, in GC_1, T viewed small-group activities as 'interesting, because each pupil models somebody else'; however, she also expressed her doubts (T_025). From GC_2 onwards, after trying the small-group structure, her conceptions of small-group activities gradually changed and she started to view the small-group format as being 'very useful for communication and language', because she could 'interact with a smaller group of pupils and tailor the support' she gave each (T_045). Furthermore, her attitude towards letting the children choose the educator they wanted to work with also started to change; in GC_4 and GC_7 some quotations attest to T's 'open-minded attitude' and 'willingness to let the children change activity' (T_082; T_136).

\section{Strategies to promote children's language development}

During the collaborative process, $\mathrm{T}$ gave importance to her training in certain strategies to promote the pupils' communication and language development and adjust her methods to suit individual pupils. Thus, in GC_1, she referred almost exclusively to the need for certain strategies to cater to diversity, meaning strategies that would allow her to tailor her practice to the individual skills of each pupil. She saw as necessary the adaptation of these strategies to each pupil, even while she felt incapable of 
adjusting to each pupil's level' (T_018). From GC_3 to GC_9, although she continued requiring specific strategies to cater to diversity, she considered herself to be better equipped to adapt to the pupils because she was more aware of the specific goals of each.

As regards language-stimulating strategies, in GC_1 she only cited general strategies, such as 'responding to the children's interventions' (T_105), 'starting from children's interests' (T_106), 'pauses' (T_107) and 'over-interpretations' (T_108) as better known and more frequently used educational strategies that could promote children's language skills. From GC_2 onwards, she mentioned certain strategies that are traditionally less cited in the literature but that they had worked on during the process: 'expanding and extending' (T_148), 'chaining' (T_149), 'repeating' (T_150) and 'reformulating' (T_151). In GC_9, T admitted that the 'Counselling process gave me training about many language-stimulating strategies' (T_152).

\section{Curriculum and educational goals}

The GC discussions also addressed the goals and curriculum in the area of communication and language. In GC_1, GC_2 and GC_3, T believed it was important to start from an Individual Plan (IP), which sets out a tailored account of goals and a methodology to use with each pupil. However, T's conception of the IPs currently used in the school was that 'they aren't very functional. There are too many goals that are unattainable in a single school year and they are not accompanied by a methodology to achieve them' (T_026). GC_1 shows that $\mathrm{T}$ saw the need for each pupil to make the progress that was required and 'not be made to do activities beyond their maturational level' (T_029) and, for this reason, she expressed 'some dissatisfaction with the school's IP' (T_028). After GC_2, all her quotations refer to educators' awareness of the good results obtained after prioritising and tailoring her pupils' goals. In GC_9, T believed that 'both actions (prioritising and tailoring pupils' goals) were needed to ensure each pupil's progress and to avoid asking all the children to complete the same task' (T_162).

\section{Teaching Assistant (TA) quotations evolution during group counselling}

Communication and language development

In GC_1, TA still considered that 'children learn to speak by imitating the adult model' (TA_002; TA_004). But already in GC_1, she was not always convinced of the importance of the educators' role and the help they offered. So, she considered that 'adult support might make the children more adultdependent' (TA_003). Her conception about educators' support became more positive during the overall process and she became aware of the importance of 'adult assistance in promoting children's language development' (TA_061). Also, at the beginning of the counselling process, she referred to 'certain innate and maturational aspects to explain the development of children's communicative competence' (TA_001). In GC_5 she also explained how one pupil with disabilities had a 'lack of initiative' (TA_039); however, after the GC_5 she did not consider maturational aspects to be decisive.

\section{The teaching assistant's role}

Regarding her conception about her role in promoting communication development, TA was highly critical of her own profile. In GC_1, she admitted that she had not received pedagogic training and defended her profile as that of someone whose job was to 'help and control the pupils so that the teacher can teach' (TA_007). However, in GC_9 her perception of her role became gradually more homogeneous with the other professionals and she stated, 'I no longer consider that my job is only to assist the teacher' (TA_063).

Another notable aspect is her change of conception about the responsibility to reflect on her practice. In GC_1 she admitted, 'I have no prior experience of video self-observation, but I have high expectations of using the video recording technique to gradually become a more reflective professional' 
(TA_008). Despite her positive initial expectations with video observations, in GC_7 she admitted, 'I still feel anxious when I observe myself on video' (TA_055).

\section{Communication style and interaction management}

With regard to TA's communication style, in GC_3 she was aware 'that this was too instructive' (TA_017). From GC_1 to GC_6, she believed that she 'should manage the classroom conversation so that each child could have communicative time' (TA_026; TA_043; TA_047). But in contrast, in GC_9 she observed that 'the way we communicate with children has changed' (TA_064).

On the other hand, although she admitted in GC_1 that 'our main educational strategy should be starting from our pupils' interests' (TA_009), her quotations at the beginning of the overall process did not mention this. For example, at the beginning, TA conceived of 'communication and language work as clearly decontextualised' and said that it did not 'take the children's interests as the point of departure' (TA_018). From GC_4 onwards, she increasingly admitted, 'I have become more flexible and I let the children start social interactions more often than I had at the beginning' (TA_066).

\section{Communication work: group size and classroom organisation}

TA did offer quotations about the group size, context and organisation to promote communication development in the classroom. It is interesting to observe how in GC_1 she said, 'The number of pupils in the classroom does not affect the children's involvement' (TA_011), but during the overall process, she also became progressively more aware of the importance of the group size. In GC_3 she admitted that 'working in small groups improves children's engagement because children and adults are more relaxed' (TA_020). In GC_4 she also stated that 'working in small groups encourages children to participate more' (TA_032). Throughout the collaborative counselling process, TA continued to think of large group activities as being useful in some areas and in GC_9 she proposed that 'working in large groups should not be avoided, but should only be used for achieving very specific goals' (TA_070).

Regarding small-group activities, in GC_1, TA viewed these as impractical for communication work' (TA_013), but from GC_2 onwards, her views gradually changed. She admitted to 'using three small groups during the same class and nothing went wrong' (TA_015), and she started to see small groups as 'being very useful for working on communication and language' (TA_036), because 'the pupils feel more relaxed, they get better-quality attention' and she could 'interact more effectively with them and tailor the support given to each child' (TA_037). In GC_9, she admitted that 'the best moment of the week is when the three educators are all in the classroom working together' (TA_071).

\section{Strategies to promote children's language development}

Regarding strategies, TA admitted, 'We can't organise the same activity for all pupils' (TA_010). From GC_1 onwards, she offered no quotations of specific strategies for catering to diversity, referring instead almost exclusively to language-stimulating strategies. In GC_4 she said, 'Most of the pupils' participation is the result of the new group organisation but it's also because of the strategies we've provided them with' (TA_030), such as 'expanding and chaining strategies' (TA_044; TA_045).

\section{Curriculum and educational goals}

TA was less critical of the curriculum, although in GC_1 she said, 'The problem in the preparation of the IP is ours. When you thought about potential goals to work on, you felt that only having two or three wouldn't be enough' (TA_014). From GC_4 onwards she was conscious of 'the benefits of having prioritised four aims per child and deciding on the particular methodology that would be required to attain these' (TA_074) and admitted that she 'had learnt the importance of adjusting to the children's level' (TA_038). 


\section{Speech Therapist (ST) quotations evolution during group counselling}

\section{Communication and language development}

Like T and TA, at the beginning of the counselling process, ST referred explicitly and frequently to certain innate and maturational aspects to explain the development of children's communicative competence. In GC_5, he described the lower level of one child's engagement as 'a passivity profile of learned helpless' (ST_043), without considering that this profile might be the result of how the educators interacted with that child. In GC_1 he also said that 'the pupils have few opportunities to learn by imitation' (ST_002) and that the way he thought they learnt was by 'adult over-interpretation' (ST_005). However, from GC_3, he gave increasing importance to offering a model to the child and, at the end of the process, he admitted that 'adult assistance is essential to give the model, extend sequences and help children expand their interests, vocabulary and communicative functions' (ST_062).

In contrast to the other educators, ST had important things to say about the family and its role in children's language development. At the beginning of the counselling, he attributed the children's lack of communicative competence to the family, 'who had not stimulated them' (ST_004; ST_032); however, ST offered no more quotations on this subject during the rest of the process, and he increasingly saw himself and the other two educators as being responsible for the children's communicative development.

\section{The speech therapist's role}

On the subject of his own role in promoting the children's language development, ST increasingly considered that this should be closely related to the educational counselling model. In GC_1, he believed his role was limited as a communication and language specialist; he was used to 'working with pupils individually' (ST_006), and he admitted 'having spent little time observing the class' (ST_007). These first conceptions contrast with the quotations collected at the end of the overall process, when he said, 'My responsibilities should not be limited to individual work with pupils but should include advising T and TA in the area of communication and language' (ST_063).

With regard to ST's initial conceptions about reflecting upon his own practices, he admitted, 'I had never used video self-observation before' (ST_023); after that, on certain occasions he cited the benefits he had gained from observing himself on video and stated, 'This technique helped me understand areas in which I needed to improve' (ST_050). In GC_9, he admitted that they 'had always been too used to being told what to do by an advisor or trainer' (ST_064) and that, once they started the collaborative process, they 'began to take their own decisions' (ST_065).

\section{Communication style and interaction management}

About his communicative style, ST admitted to 'interacting with the pupils in a style that was much too directive, especially with pupils with more serious communicative disorders' (ST_009). Again, 'the communicative turn was a recurrent issue' (ST_033; ST_034; ST_038; ST_046). From GC_2, when he started to interact more with pupils in small-group activities, he frequently said, 'I am still more comfortable working on a one-to-one basis within small groups' (ST_066). Note, too, that ST was the one who spoke most about the difficulty of basing activities on the children's interests and he admits to 'being more comfortable programming the activities beforehand, even though these are then decontextualised and do not take their cue from children's interests' (ST_058; ST_067).

\section{Communication work: group size and classroom organisation}

There was a change in how ST thought he should do his work. Initially, in GC_1, he conceived of his task as one that should be tackled outside the classroom, where he could 'recreate planned pair-work 
activities in order to make the most of the time and focus on very specific aspects that cannot be addressed in routine classroom activities' (ST_018). In GC_1, he also admitted to 'being more comfortable working with children alone than doing large-group activities' (ST_015), but said that he was 'open to the idea of trying different kinds of groupings' (ST_014), although he had 'certain doubts about the functionality of small-group activities' (ST_020). From GC_2 onwards, he began to move away slightly from the specialist and individualised model and started to recognise 'the benefits of having the children work in small groups within the natural classroom context' (ST_070), although he was the only participant who admitted to feeling 'more comfortable with dyadic work than small-group activities' (ST_040; ST_059; ST_072). In GC_3, he stated that his work as a speech therapist had been 'fully incorporated in the classroom' (ST_036), and in GC_4 he said, 'I have reduced the hours of individual speech therapy and have tried to work with them more in the classroom context' (ST_041). Also, from GC_2 onwards, he tried to be more flexible by 'letting children move from one group to another because they want to' (ST_029), although in GC_3 he confessed that 'it's been hard' (ST_037).

\section{Strategies to promote children's language development}

About the strategies used by the educators that are useful for children's language development, in GC_1, ST cited only the 'over-interpretation' (ST_003). From GC_5 onwards, he started to cite other less well-known strategies like 'expanding' (ST_022), 'correcting' (ST_024) and 'positive feedback' (ST_025). On the other hand, he did not participate in the discussion about the need to use strategies to adjust to class diversity.

\section{Curriculum and educational goals}

ST offered few quotations related to the curriculum program and educational goals. In GC_1, he stated, 'I'm aware that I sometimes force the child to do things over his head' (ST_021). In GC_2, he accepted that 'the IPs are too long; we should make the aims more tailored to the children's needs and more relevant to the short-term' (ST_030).

\section{Discussion}

The main goal of this study was to identify and describe, through a collaborative counselling model consisting of nine GC sessions, the changes that three teaching professionals experienced in their conceptions about their work on communication and language. The work carried out in the GCs consisted of starting from what educators already thought and encouraging them to engage in a shared discussion on a particular understanding of communication and language development. During the nine GCs, educators and counsellors took their decisions jointly, and the professionals' capacity for selfevaluation (Keiny \& Dreyfus, 1989; Marsh \& Mitchell, 2014; Schön, 1992) and autonomy was increasingly reinforced by tools and strategies to help them take their own decisions (Bogler \& Somech, 2004; Klein, 2016). Qualitative analysis indicates that there was a subtle change in the way T, TA and ST conceived of development processes and language teaching-learning, the factors involved in such processes, and the context in which their practices should be used.

The themes dealt with during the nine GCs were diverse, and each session attempted to address a specific theme present in the social-interactionist theory of communication and language development. For this reason, we can see that certain thematic areas appear more frequently in one GC than in another, depending on the theme being addressed.

About teaching professionals' views on how children develop communication and language competence, and on the teaching-learning processes that inform this development, our research shows that their conceptions subtly changed in number of ways. At the beginning of the counselling process, T, TA and ST still based their professional performance on theories of communication and language 
teaching-learning that were uninformed by the social-interactionist perspective (Coll \& Martín, 2006; Gràcia et al., 2012). Specifically, T and TA considered that their support as a crutch that might make the pupils more adult-dependent. We also found that they started from maturational and nativist conceptions of language development; for example, they claimed that some pupils had more communication resources than others, without linking this fact to the kind of stimulation the children had experienced at school but instead pointing to merely innate aspects as the source of the children's resources. In the course of the group counselling, the educators slightly moved away from nativist theories and began to assign themselves a more relevant role as promoters of pupil language development.

Other areas of change during the discussions in the GCs were the educators' conceptions about the importance of their communication style and interaction management when they interacted with pupils with disability. As other researchers have observed (Conti-Ramsden, Hutcheson, \& Grove, 1995; File, 1994), the three teaching professionals were aware that they modified their interactive style with such pupils and that it initially tended to be more directive, planned, artificial and less participatory. However, their conception about the adult's need to manage the interaction gradually changed. From GC_1 to GC_6, they believed that it was important to use communicative turns to manage the conversation and to provide communicative time to each child. However, from GC_2 onwards, they talked less about the need to interrupt the most communicative children and gave time for the quieter pupils, and they gradually became aware of the importance of being less directive and letting the children initiate more turns by themselves. That kind of change in their conceptions could reflect the progressive training they received and the incorporation of certain language-stimulating strategies to model, expand and extend the children's utterances and follow their lead. So, as happened in previous training processes (Weitzman \& Greenberg, 2002; Weitzman et al., 2006), the three professionals became progressively more aware of the importance of their communication style when they interacted with their pupils; for example, through the use of frequent, high-quality interactions (Weitzman et al., 2006).

Regarding the participants' conceptions of their role as education professionals, the results show that at the beginning of the collaborative counselling, the three educators started from established teaching habits, formed as the result of past experiences and teaching practices. At first, they demonstrated a relatively unreflective attitude about their own teaching practices, although they were aware that they were repeating behaviours they had observed in their peers. As Delval (2002) states, they conceived of teaching-learning processes as others did or as they remembered having been taught, and those conceptions influence how teaching practice continues, determining the way teachers make decisions (Clarà, 2014). The debates our three professionals had in the course of the nine GCs and the self-observations could have been useful tools to help them promote a more reflective attitude, more evident in T's case. Indeed, some of their conversations together during the GCs helped them to be aware of themes they had never dealt with before; for instance, they became aware that they viewed the drafting of pupils' IPs as unhelpful and they began to think about changing its wording. During GC_1, especially T, who is responsible for designing the curricular activities, began to appreciate the need to prioritise aims and considered that these should be achievable, tailored to each child, sorted by priority, worked on in everyday natural situations (Manolson, Ward, \& Dodington, 1995), and accompanied by a methodology (Casey \& McWilliam, 2011).

Also on the subject of their professional role, the qualitative analysis of GC_1 indicates that the educators linked each professional role with their previous training. We were able to confirm that $\mathrm{T}$ and TA expressed that they had not received specific training in the area of communication and language or in strategies to promote language development, as other studies have also indicated about other such professionals (Larraz, 2006). For this reason, at the beginning of the overall process, all of the three teaching professionals conceived of communication and language work as solely the responsibility of the ST, who worked individually with the pupils outside the classroom. Furthermore, the TA understood her work only involved controlling the children's behaviour and ensuring that they were seated and listening to the T's explanation (Fennick \& Liddy, 2001; Gràcia, Benítez, Vega, \& Domeniconi, 2015; Pellegrino \& Scopesi, 1990). During the discussions in GC_1, T and TA began 
to think about the appropriateness of the organisation of the classroom and decided to bring the ST into the class in order to have all three of them there with a more homogeneous role and to meet pupils' needs more effectively in small-group activities. At the end of the overall process, the three teachers conceived of their individual professional roles more homogeneously; for example, T stated: 'The work on communication could be taken up by any professional.' In addition, they valued organising activities with fewer pupils to offer more tailored help and attention (Gràcia, Benítez et al., 2015; Weitzman et al., 2006), which allowed them to interact with a less directive style (O’Brien \& Bi, 1995; Pellegrino \& Scopesi, 1990).

Related to the conceptual changes presented above, some changes were also observed in the way educators conceived of the optimal activities for promoting communication and language. In GC_1, they deemed it necessary and justifiable to create artificial activities to work on communication and language aims, which were rarely based on the children' interests or prior knowledge. This confirms data from previous studies in which special educators demonstrate an instructional style marked by a choice of conversational themes and a design of activities that do not take into account the pupils' interests but rather control their behaviour throughout the activities (Urbach et al., 2015). It seems that during the overall process, the teaching professionals in our study progressively shared more aspects with the counsellors who came from a more social-interactionist and eco-functional perspective; and they also began to give more importance to the use of interactive classroom routines based on the children's interests when working on communication and language. They began to be aware of the reduced functionality of organising artificial activities that were unrelated to the children's day-today existence, and began to see the benefits of using routine classroom situations to work on communication and language, based on children's interests and following their lead (Manolson et al., 1995; Weitzman et al., 2006). However, it was not always easy for all of them to do this; in particular, the ST explained he had difficulty allowing the pupils to change activity and to start from their own interests.

The results described above confirm that the three professionals started the intervention with an outdated way of conceiving their professional role, the classroom organisation and the kind of the activities that favour the development of communication and language. Those initial conceptions are framed within a specialist model that is considered obsolete in many countries because it does not align with current evidence-based approaches to supporting students with disabilities in the school context, and does not uphold children's rights to participate in the curriculum (Gallagher, Tancredi, \& Graham, 2018; Hopf, 2018; McEwin \& Santow, 2018; Murphy, Lyons, Carroll, Caulfield, \& De Paor, 2018). Although the research shows poor results in terms of children's language development with this specialist intervention approach in comparison to other more socio-interactive models (DeVeney, Hagaman, \& Bjornsen, 2017), this model is still frequently used in Spanish special schools (Luque, Hernández, Fernández, \& Carrión, 2019; Muntaner, 2019). It is interesting to highlight these aspects to understand why, in the Spanish context, suggestions that may seem normal in other contexts, such as the incorporation of small-group interventions into special-school classrooms and the use of a more receptive style of interaction, were conceived as innovative and were very difficult to achieve for the three participating educators.

To conclude, the collaborative counselling implemented seems to have been useful to generate bidirectional relationships between counsellors and teaching professionals (Sakız \& Sarıçali, 2019; Yu, 2011). This process has led to the creation of spaces to allow educators to analyse their conceptions about communication and language development and teaching-learning processes, thus enabling them to progressively re-describe these with the help of self-critical skills (Schön, 1992). Note that we have designed and implemented an intervention to promote change in three teaching professionals' conceptions, attitudes, beliefs and perceptions about communication and language development. We presume that such teaching professionals' conceptual change will lead to specific changes in their classroom practices, which in turn will improve student competence (Vega, 2018). For this reason, future research will need to consider how far the changes in the three teaching professionals' conceptions were also followed by changes in their performance in classroom and in pupils' linguistic competence. 
Acknowledgements. The authors wish to thank EMEE FATIMA for taking part in the research, and especially the teacher, teaching assistant, speech therapist and pupils who directly participated in the study.

Funding. This study was supported by a grant from the Agency for the Management of University and Research Grants of the Government of Catalonia (AGAUR, Generalitat de Catalunya, FI-DGR-2012) and by the Research Group in Education Sciences (Agrupació de Recerca en Ciències de l'Educació) of the University of Barcelona.

\section{References}

Bogdan, R., \& Biklen, S. (1998). Qualitative research in education. Boston, MA: Allyn \& Bacon.

Bogler, R., \& Somech, A. (2004). Influence of teacher empowerment on teachers' organisational commitment, professional commitment and organisational citizenship behavior in schools. Teaching and Teacher Education, 20, 277-289.

Brady, K., \& Woolfson, L. (2008). What teacher factors influence their attributions for children's difficulties in learning? British Journal of Educational Psychology, 78, 527-544.

Brantlinger, E., Jimenez, R., Klingner, J., Pugach, M., \& Richardson, V. (2005). Qualitative studies in special education. Exceptional Children, 71, 195-207.

Bronfenbrenner, U. (1987). Family support: The quiet revolution. In S. Dans, L. Kagan, D. Powell, B. Weissbourd, \& E. Zigler (Eds.), America's Family Support Programs (pp. 11-17). New Haven, CT: Yale University Press.

Bruner, J. (1986). El habla del niño: aprendiendo a usar el lenguaje. Barcelona, Spain: Paidós.

Cabell, S., Justice, L., Piasta, S.B., Curenton, S.M., Wiggins, A., Turnbull, K.P., \& Petscher, Y. (2011). The impact of teacher responsivity education on preschoolers' language and literacy skills. American Journal of Speech-Language Pathology, 20, 315-330.

Carr, D. (2007). Character in teaching. British Journal of Educational Studies, 55, 369-389.

Casey, A.M., \& McWilliam, R.A. (2011). The characteristics and effectiveness of feedback interventions applied in early childhood settings. Topics in Early Childhood Special Education, 31, 68-77.

Cash, A.H., Cabell, S.Q., Hamre, B.K., DeCoster, J., \& Pianta, R.C. (2015). Relating prekindergarten teacher beliefs and knowledge to children's language and literacy development. Teaching and Teacher Education, 48, 97-105.

Clarà, M. (2014). Understanding teacher knowledge from a cultural psychology approach. Teaching and Teacher Education, 43, 110-119.

Coll, C., \& Martín, E. (2006). Vigencia del debate curricular: aprendizajes básicos, competencias y estándares [Validity of the curriculum debate: Learning, competencies and standards]. Mexico City, Mexico: Secretary of Public Education.

Conti-Ramsden, G., Hutcheson, G.D., \& Grove, J. (1995). Contingency and breakdown: children with SLI and their conversations with mothers and fathers. Journal of Speech, Language, and Hearing Research, 38, 1290-1302.

Delval, J. (2002). Entrevista a Juan Delval [Interview of Juan Delval]. Investigación en la Escuela, 43, 71-80.

DeVeney, S.L., Hagaman, J.L., \& Bjornsen, A.L. (2017). Parent-implemented versus clinician-directed interventions for late-talking toddlers: A systematic review of the literature. Communication Disorders Quarterly, 39, 293-302.

Fennick, E., \& Liddy, D. (2001). Responsibilities and preparation for collaborative teaching: Co-teachers' perspectives. Teacher Education and Special Education, 24, 229-240.

File, N. (1994). Children's play, teacher-child interactions, and teacher beliefs in integrated early childhood programs. Early Childhood Research Quarterly, 9, 223-240.

Flowers, H., Girolametto, L., Weitzman, E., \& Greenberg, J. (2007). Promoting early literacy skills: Effects of in-service education for early childhood educators. Canadian Journal of Speech-Language Pathology and Audiology, 31, 6-17.

Gallagher, A., Tancredi, H., \& Graham, L.J. (2018) Advancing the human rights of children with communication needs in school. International Journal of Speech-Language Pathology, 20, 128-132.

Girolametto, L., Weitzman, E., Lefebvre, P., \& Greenberg, J. (2007). The effects of in-service education to promote emergent literacy in child care centres: a feasibility study. Language, Speech, and Hearing Services in Schools, 38, 72-83.

Gràcia, M., Ausejo, R., \& Porras, M. (2010). Intervención temprana en comunicación y lenguaje: Colaboración con las educadoras y familias de dos niños [Early intervention in communication and language: Collaboration with educators and families of two children]. Revista de Logopedia, Foniatría y Audiología, 30, 186-195.

Gràcia, M., Benítez, P., Vega, F., \& Domeniconi, C. (2015). Escala de valoración de la enseñanza del lenguaje oral en contexto escolar: adaptación para su uso en educación especial [Assessment scale of oral language teaching in school context: Adaptation for use in special education]. Revista de Logopedia, Foniatría y Audiología, 35, 84-94.

Gràcia, M., Galván-Bovaira, M.J., Sánchez-Cano, M., Vega, F., Vilaseca, R., \& Rivero, M. (2015). Valoración de la enseñanza de la lengua oral. Escala EVALOE [Assessment of oral language teaching. EVALOE scale]. Barcelona, Spain: Graó.

Gràcia, M., Galván-Bovaira, M.J., Vilaseca, R., Rivero, M., \& Sánchez-Cano, M. (2012). El cambio conceptual de dos maestras en relación con la enseñanza y el aprendizaje de la lengua oral a través de un asesoramiento: un estudio de casos [The conceptual change of two teachers in relation to teaching and learning oral language through a counselling: A case study]. Revista de Logopedia, Foniatría y Audiología, 32, 179-189. 
Gràcia, M., \& Segués, T. (2009). Psicología de la educación y de la instrucción [Educational and instructional psychology]. Barcelona, Spain: Fundació Universitat Oberta de Catalunya.

Gràcia, M., Vega, F., \& Galván-Bovaira, M.J. (2015). Developing and testing EVALOE: A tool for assessing spoken language teaching and learning in the classroom. Child Language Teaching and Therapy, 31, 287-304.

Gutiérrez, A.I., \& Rosas, M.Y. (2008). El lugar de la oralidad en la escuela: exploraciones iniciales sobre las concepciones de los docentes [The place of orality in schools: Initial explorations about teachers' conceptions]. Infancias Imágenes, 7, 24-29.

Hamre, B., Pianta, R.C., Burchinal, M., Field, S., LoCasale-Crouch, J., Downer, J.T., \& Scott-Little, C. (2012). A course on effective teacher-child interactions: Effects on teacher beliefs, knowledge, and observed practice. American Educational Research Journal, 49, 88-123.

Hollenbeck, A. (2013). Beyond talking about books: Implications of the reading comprehension instruction and pedagogical beliefs of a special educator perceived as effective. Learning Disability Quarterly, 36, 112-125.

Hopf, S. (2018). Communication capacity research in the majority world: Supporting the human right to communication specialist services. International Journal of Speech-Language Pathology, 20, 84-88.

Hudry, K., Leadbitter, K., Temple, K., Slonims, V., McConachie, H., Aldred, C., .. Pact Consortium. (2010). Preschoolers with autism show greater impairment in receptive compared with expressive language abilities. International Journal of Language \& Communication Disorders, 45, 681-690.

Karmiloff-Smith, B.A. (1994). Beyond modularity: A developmental perspective on cognitive science. European Journal of Disorders of Communication, 29, 95-105.

Kaye, K. (1982). The mental and social life of babies: How parents create persons. Brighton, UK: Harvester.

Keiny, S., \& Dreyfus, A. (1989). Teachers' self-reflection as a prerequisite to their professional development. Journal of Education for Teaching, 15, 53-63.

Klein, J. (2016). Teacher empowerment, horizontal and vertical organisational learning, and positional mobility in schools. European Journal of Teacher Education, 39, 238-252.

Krippendorff, K. (2012). Content analysis: An introduction to its methodology (3rd ed.). Thousand Oaks, CA: Sage.

Kumin, L. (2008). Helping children with Down syndrome communicate better. Speech and language skills for ages 6-14. Bethesda, MD: Woodbine House.

Larraz, C. (2006). Comunicación Aumentativa [Augmentative Communication]. Minusval, Dossier de comunicación aumentativa y alternativa, 160, 17-19.

Leko, M.M., Kulkarni, S., Lin, M.C., \& Smith, S.A. (2014). Delving deeper into the construct of preservice teacher beliefs about reading instruction for students with disabilities. Teacher Education and Special Education, 38, 186-206.

Luna, M., \& Martín, E. (2007). La importancia de las concepciones en el asesoramiento psicopedagógico [The importance of conceptions in psychopedagogical counselling]. Profesorado. Revista de currículum y formación del profesorado, 12, 1-12.

Luque, A., Hernández, C.M., Fernández, M., \& Carrión, J.J. (2019). Itinerant hearing and language professors: collaborative work, pending challenge for a new profile. Revista Educación, 43, 170-182.

Manolson, A., Ward, B., \& Dodington, N. (1995). You make the difference in helping your child learn. Toronto, Canada: The Hanen Centre.

Markauskaite, L., \& Goodyear, P. (2014). Tapping into the mental resources of teachers' working knowledge: Insights into the generative power of intuitive pedagogy. Learning, Culture and Social Interaction, 3, 237-251.

Marsh, B., \& Mitchell, N. (2014). The role of video in teacher professional development. Teacher Development, 18, $403-417$.

Martín, E., \& Solé, I. (2011) Orientación educativa: Modelos y estrategias de intervención [Educational guidance: Models and intervention strategies]. Barcelona, Spain: Graó.

McDonald, D., Proctor, P., Gill, W., Heaven, S., Marr, J., \& Young, J. (2015). Increasing early childhood educators' use of communication-facilitating and language-modelling strategies: Brief speech and language therapy training. Child Language Teaching and Therapy, 31, 305-322.

McEwin, A., \& Santow, E. (2018). The importance of the human right to communication, International Journal of SpeechLanguage Pathology, 20, 1-2.

McMillan, J.H., \& Schumacher, S. (2014). Research in education: Evidence-based inquiry. New York: Pearson Higher Education.

Muhr, T. (2013). ATLAS.ti (Version 7.0) [Computer software]. Berlin, Germany: Scientific Software Development.

Muntaner, J. (2019). Consideraciones para la intervención de los apoyos de la comunicación y el lenguaje en la escuela inclusiva [Considerations for the intervention on communication and language supports in the inclusive school]. Revista de Logopedia, Foniatría y Audiología, 39, 41-48.

Murphy, D., Lyons, R., Carroll, C., Caulfield, M., \& De Paor, G. (2018). Communication as a human right: Citizenship, politics and the role of the speech-language pathologist. International Journal of Speech-Language Pathology, 20, 16-20.

O'Brien, M., \& Bi, X. (1995). Language learning in context teacher and toddler speech in three classroom play areas. Topics in Early Childhood Special Education, 15, 148-163.

Pellegrino, M., \& Scopesi, A. (1990) Structure and function of baby talk in a day-care centre. Journal of Child Language, 17, 101-114. 
Piasta, S.B., Justice, L., Cabell, S.Q., Wiggins, A.K., Turnbull, K.P., \& Curenton, S.M. (2012). Impact of professional development on preschool teachers' conversational responsivity and children's linguistic productivity and complexity. Early Childhood Research Quarterly, 27, 387-400.

Porlán, R., Rivero, A., \& Martín del Pozo, R. (1997). Conocimiento profesional y epistemología de los profesores I: Teoría, métodos e instrumentos [Professional knowledge and epistemology of teachers I: Theory, methods and instruments]. Enseñanza de las Ciencias, 15, 155-171.

Pozo, J.I., Scheuer, N., Pérez, M.P., Mateos, M., Martín, E., \& De la Cruz, M. (2006). Nuevas formas de pensar la enseñanza y el aprendizaje. Las concepciones de profesores y alumnos [New ways of thinking about teaching and learning. Teachers and students' conceptions]. Barcelona, Spain: Graó.

Ruppar, A.L., Gaffney, J.S., \& Dymond, S.K. (2015). Influences on teachers' decisions about literacy for secondary students with severe disabilities. Exceptional Children, 81, 209-226.

Sakız, H., \& Sarıçalı, M. (2019). Paradigmatic Challenges in School Counselling: Correlates and Reflections on Practice. Journal of Psychologists and Counsellors in Schools, 29, 69-81.

Sandvik, J.M., van Daal, V., \& Adèr, H.J. (2014). Emergent literacy: Preschool teachers' beliefs and practices. Journal of Early Childhood Literacy, 14, 28-52.

Scarinci, N., Rose, T., Pee, J., \& Webb, K. (2015). Impacts of an in-service education program on promoting language development in young children: A pilot study with early childhood educators. Child Language Teaching and Therapy, 31, 37-51.

Schachter, R.E., Spear, C.F., Piasta, S.B., Justice, L.M., \& Logan, J.A. (2016). Early childhood educators' knowledge, beliefs, education, experiences, and children's language and literacy learning opportunities: What is the connection? Early Childhood Research Quarterly, 36, 281-294.

Schön, D. (1992). Educating the reflective practitioner. San Francisco, CA: Jossey-Bass.

Ukrainetz, T.A., \& Fresquez, E.F. (2003). What isn't language? A qualitative study of the role of the school speech-language pathologist. Language, Speech, and Hearing Services in Schools, 34, 284-298.

Urbach, J., Moore, B.A., Klingner, J.K., Galman, S., Haager, D., Brownell, M.T., \& Dingle, M. (2015). 'That's my job': Comparing the beliefs of more and less accomplished special educators related to their roles and responsibilities. Teacher Education and Special Education, 38, 323-336.

Vega, F. (2018). Asesoramiento a docentes de escuela especial para mejorar su práctica en relación con el desarrollo de la comunicación y el lenguaje de sus alumnos. [Counseling to special school teachers to improve their practice in relation to the students' communication and language development]. Published doctoral dissertation. Barcelona: Universidad de Barcelona. Available in: https://www.tdx.cat/handle/10803/667015\#page=364.

Vega, F., \& Gràcia, M. (2016). Asesoramiento a docentes en el uso de un sistema aumentativo y alternativo de comunicación [Coach to teachers in the use of an augmentative and alternative communication system]. Revista de Investigación en Logopedia, 6, 169-202.

Weitzman, E., Girolametto, L., \& Greenberg, J. (2006). Adult responsiveness as a critical intervention mechanism for emergent literacy: Strategies for preschool educators. In L.M. Justice (Ed.), Clinical approaches to emergent literacy intervention. A volume in the emergent and early literacy series (pp. 127-178). San Diego, CA: Plural Publishing.

Weitzman, E., \& Greenberg, J. (2002). Learning language and loving it: A guide to promoting children's social, language, and literacy development in early childhood settings. Toronto, Canada: The Hanen Centre.

Yin, R. (2006). Case study methods. In J.L. Green, G. Camilli, \& P.B. Elmore (Eds.), Handbook of Complementary Methods in Education Research (pp. 111-122). Mahwah: Erlbaum.

Yu, K. (2011). Exploring the nature of the researcher-practitioner relationship in qualitative educational research publications. International Journal of Qualitative Studies in Education, 24, 785-804.

Cite this article: Vega F, Gràcia M, and Riba C. Collaborative counselling: influence on the teaching professionals' conceptions as promoters of children's communication and language. Journal of Psychologists and Counsellors in Schools. https://doi.org/ 10.1017 /jgc. 2019.25 